\title{
Randomized clinical trials of patients with acute myocardial infarction-related cardiogenic shock: a systematic review of used cardiogenic shock definitions and outcomes
}

\author{
Jakob Josiassen', Martin Frydland', Christian Hassager', Jacob Eifer Møller',2, Anders Perner', Johannes Grand' \\ 'Department of Cardiology Rigshospitalet, University of Copenhagen, Copenhagen, Denmark \\ 2Department of Cardiology, Odense University Hospital, Odense, Denmark \\ ${ }^{3}$ Department of Intensive Care, Rigshospitalet, University of Copenhagen, Copenhagen, Denmark
}

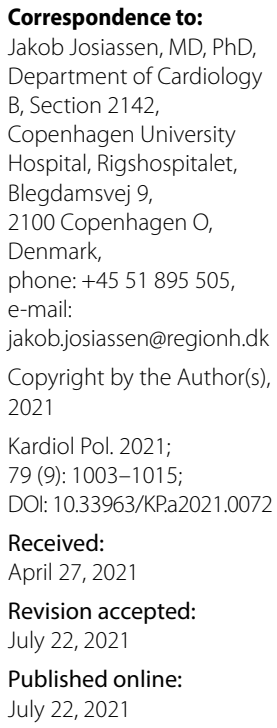

Correspondence to:

Jakob Josiassen, MD, PhD, Department of Cardiology B, Section 2142 ,

Copenhagen University Hospital, Rigshospitalet, Blegdamsvej 9,

2100 Copenhagen O, Denmark, phone: +45 51895 505, e-mail:

jakob.josiassen@regionh.dk Copyright by the Author(s), 2021

Kardiol Pol. 2021;

79 (9): 1003-1015;

DOI: 10.33963/KP.a2021.0072

Received:

April 27, 2021

Revision accepted:

July 22, 2021

Published online:

July 22, 2021

\begin{abstract}
A B S TR A C T
Background: Cardiogenic shock (CS) is a critical complication to acute myocardial infarction (AMI), with short-term mortality rates exceeding $40 \%$. However, no international consensus of a CS definition exists. This may compromise interstudy comparability.
\end{abstract}

Aims: The aim of the current study was to review differences and similarities of CS enrolment criteria in AMI-related CS randomized clinical trials (RCT).

Methods: From the electronic databases MEDLINE and EMBASE we identified all AMI-related CS trials.

Results: A total of 19 trials comprising a total of 2674 unique patients with CS were identified. Seven trials investigated left ventricular assist devices, eight investigated medical treatments, three percutaneous coronary intervention ( $\mathrm{PCl}$ ), and one trial investigated targeted temperature management. The inclusion criteria, baseline hemodynamics, endpoints, and mortality varied markedly between trials. Hypotension was the most frequent overall inclusion criterion (17 [90\%] trials), and a systolic blood pressure $<90 \mathrm{~mm} \mathrm{Hg}$ (and/or need of vasopressors) was the most frequently used limit. Twelve $(63 \%)$ trials had signs of impaired end-organ perfusion as an inclusion criterion and 10 (53\%) signs of impaired cardiovascular function most frequently low cardiac index and reduced left ventricular ejection fraction. Ten (53\%) trials included patients resuscitated from a cardiac arrest, three trials excluded cardiac arrest patients whereas six trials did not state whether cardiac arrest was an exclusion criterion. Mortality ranged from $8 \%$ to $73 \%$.

Conclusions: The RCTs of AMI-related CS have marked heterogeneity in enrolment criteria and outcomes potentially hampering interstudy comparability. The overall consensus of CS enrolment criteria appears needed for future selection of patients.

Key words: acute heart failure, acute myocardial infarction, cardiac arrest, cardiogenic shock, randomized controlled trial

Kardiol Pol 2021; 79, 9: 1003-1015

\section{INTRODUCTION}

Mortality related to acute myocardial infarction (AMI) has declined dramatically during the past decades [1]. However, $5 \%-10 \%$ of AMI patients deteriorate to cardiogenic shock (CS), which is associated with in-hospital mortality rates exceeding 40\% [1-3]. Cardiogenic shock is a low-cardiac output state with end-organ hypoperfusion and adequate ventricular filling [4]. Several advanced pharmacological therapies and devices are available, however, only limited data to support the use of these interventions are available and the patient selection seems crucial $[5,6]$. CS can be de- fined as "a state in which ineffective cardiac output caused by a primary cardiac disorder results in both clinical and biochemical manifestations of inadequate tissue perfusion" [7] or "the inability of the heart, generally as a result of impairment of its pumping function, to deliver an adequate amount of blood to the tissues to meet resting metabolic demands" [8]. From these definitions, it can be deduced that CS is a syndrome of (1) low cardiac output caused by, (2) cardiac dysfunction, leading to (3) tissue hypoperfusion. CS patients encompass a broad spectrum of hemodynamic states with differing degrees of shock leading to substan- 
WHAT'S NEW?

An international consensus with regards to patient enrolment criteria in randomized clinical trials of cardiogenic shock patients is lacking. In the current study we observed marked differences in used cardiogenic shock definitions between the existing randomized clinical trials. This also applied among ongoing studies currently enrolling patients. These varying definitions limit interstudy comparability. A future consensus of overall cardiogenic shock enrolment criteria appears needed and beneficial.

tial heterogeneity in CS study populations. In AMI-related CS, patients may begin with clinical signs of CS without increased lactate/hypoperfusion. Expert consensus has a novel CS classification categorizing patients with or at risk of CS into 5 worsening stages of CS. Hypotension necessitating vasoactive pharmacological treatment or mechanical circulatory support is often present [7, 9]. However, the clinical presentation can vary significantly between patients, possibly delaying the diagnosis and treatment [7]. Some trials mandate objective measures of reduced cardiac function [10], whereas others rely on clinical assessment combined with increased lactate [11]. So far, no international consensus on a CS definition has been established, why interstudy comparison remains challenging. Also, it is debated whether trials of CS should include patients successfully resuscitated from cardiac arrest [12], which make up approximately half of the patients in contemporary CS trials [11,13]. Cardiogenic shock and cardiac arrest often occur together, however some aspects of pathophysiology etiologies and cause of in-hospital death (anoxic brain injury vs acute intractable cardiac failure) [14] differs substantially, suggesting that patients with concomitant cardiac arrest and CS possibly should be analyzed separately from patients with CS without cardiac arrest in clinical trials [12]. In this systematic review, inclusion criteria used in randomized controlled acute myocardial infarction-related CS trials have been described and critically appraised. Additionally, we provide an overview of endpoints used in existing and ongoing CS trials.

\section{METHODS}

\section{Search strategy}

\section{Published studies}

With the assistance of an expert scientific librarian, we developed search strategies and applied them to the electronic databases MEDLINE and EMBASE. All searches were run on September 10, 2020, and included all RCTs since 1999. The search strategy included Medical Subject Headings (MeSH) for MEDLINE and keywords related to CS and AMI. An overview of the complete search strategy is available upon request.

\section{Study selection}

Eligibility criteria for inclusion in this review required that studies were on human subjects conducted in adults with CS and were full-text articles written in English. We included studies without limitation on sample size. We excluded reviews, commentaries, editorials, letters to the editor, studies where only the abstract was available, case reports, case series, and studies of CS which were not prospective, randomized, controlled trials (RCTs). Furthermore, we excluded studies, in which CS patients were a subgroup of a larger study. References were checked from the included studies and included if relevant.

Each study abstract was assessed independently by two investigators ( $J J$ and $J G$ ). We used the software package Covidence, which is an online tool for systematic reviews (www.covidence.org). The software allows upload and evaluation of searches of abstracts and full texts by each investigator blinded to the other evaluator's decision. Disagreements were marked for later evaluation. We resolved such cases using a third reviewer (MF). After screening abstracts, all the studies that met the inclusion criteria went through full-text screening by JJ and JG.

\section{Data extraction}

We then extracted data from each study using a standardized, pilot-tested form. Extracted data included study characteristics (study title, authors, year of publication, study design, number of included patients, inclusion and exclusion criteria, details of the intervention, and endpoints). Inclusion criteria were grouped into basic hemodynamics (heart rate, blood pressure), advanced hemodynamics/cardiac function (left ventricular ejection fraction [LVEF], cardiac index, pulmonic-capillary wedge pressure [PCWP], central venous pressure [CVP]), signs of end-organ hypoperfusion, and biomarkers (lactate). In cases of multiple publications of the same trial, the original publication would be given priority. If data seemed to be missing from a trial, we tried to acquire the data through correspondence with the trial authors. We contacted the corresponding authors of nine trials for missing data, of which five answered [5, 10, 15-17]. Data extraction was conducted by two reviewers ( $J$ J and JG) and independently checked by one further reviewer (MF). Following the extraction of data, careful consideration was given to the suitability of conducting a meta-analysis. As the trials were too heterogeneous, the data were synthesized qualitatively.

\section{Ongoing and future trials}

A search for the overall term "Cardiogenic shock" was run on ClinicalTrials.gov on September 10, 2020. A total of 19 trials studying CS are currently registered, of which 8 are relevant for this systematic review. Data was extracted 
similarly to the method described above and presented in the supplementary.

\section{Ethics}

The study was conducted in accordance with the national and institutional ethical guidelines.

\section{Statistical analysis}

The results are presented as percentages of the total number of published AMI-related CS RCTs.

\section{RESULTS}

The search strategy identified 513 studies and another three were identified through other sources. Of these, 73 were duplicates. After screening of titles and abstracts, 480 studies were excluded for not meeting our inclusion criteria. Two authors (JG and JJ) reviewed the full text of 35 studies, identifying 19 RCTs for inclusion in this review. Details are provided in a Preferred Reporting Items for Systematic Reviews and Meta-Analyses (PRISMA) flow diagram shown in Figure 1.

\section{Study characteristics}

Seven trials investigated mechanical circulatory assist devices such as an intra-aortic balloon pump, TandemHeart ${ }^{\circledast}\left(\right.$ LivaNova, London, UK) and Impella ${ }^{\circledR}$ (Abiomed, Danvers, MA, USA) [16, 18-22], 8 trials investigated pharmacological treatments [15, 17, 23-28], 3 investigated coronary interventions $(\mathrm{PCl})[10,13,29]$, and 1 trial investigated targeted temperature management [16]. The trials were published from 1999 onwards. Two trials included more than 500 patients $[11,13]$. Another two trials included 250-500 patients $[10,15]$. However, the majority of trials were small and included less than 100 patients. A total of 2674 unique individual patients were randomized in the reviewed trials. Follow-up periods, as well as endpoints of the trials, differed markedly, with mortality being the most common primary endpoint or part hereof in 8 (42\%) trials. Study characteristics, sample size, publication year, endpoints, and intervention investigated, are summarized in Table 1.

\section{Definition of cardiogenic shock}

A persisting systolic blood pressure (SBP) value $<90 \mathrm{~mm} \mathrm{Hg}$ and/or vasopressor requirements were the most frequent inclusion criteria and were used in $13(68 \%)$ trials [10, 11, $13,17-20,22-24,26,29,30]$. Three (16\%) trials used an SBP value $<100 \mathrm{~mm} \mathrm{Hg}[15,25,27]$ and 1 (5.3\%) trial used SBP $<80 \mathrm{~mm} \mathrm{Hg}$ [21]. No trials used mean arterial or diastolic blood pressure, while 3 trials included heart rate $[10,17$, 25]. A total of $12(63 \%)$ trials required signs of impaired end-organ perfusion [10, 11, 15, 17, 19-23, 26, 30], with clinical assessment being a central part of which 10 trials required at least 1 of several possible symptoms; 11 trials (58\%) included low urine output defined either as a urine output $<30 \mathrm{ml} / \mathrm{h}$ or more unspecific as "oliguria" [10, 11, $13,15,19-23,26,30]$. Altered mental status was used in $6(32 \%)$ trials $[11,13,22,23,26,30]$ and clinically assessed cold and/or clammy skin and limbs was used in 12 trials $(63 \%)[10,11,13,15,17,19-23,26,30]$. Elevated arterial

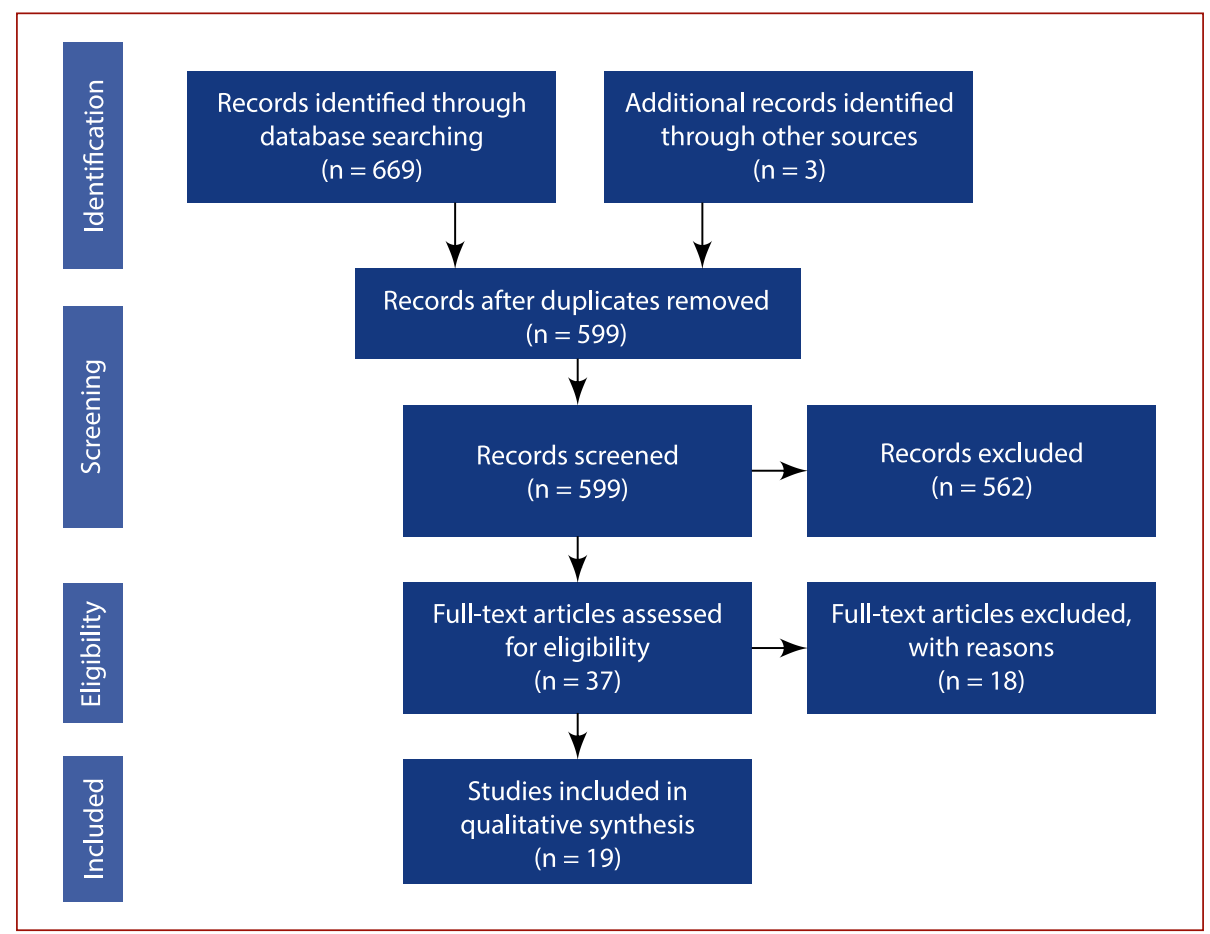

Figure 1. Preferred Reporting Items for Systematic Reviews and Meta-Analyses (PRISMA) flow diagram of reviewed and included trials. Reasons for full text exclusion: substudy to already included study $(n=3)$, protocol future study $(n=1)$, not randomized controlled trial $(n=3)$, methods insufficiently described $(n=1)$, including other patients than cardiogenic shock $(n=3)$, including other patients than myocardial infarction $(n=5)$ 
Table 1. Study characteristics

\begin{tabular}{|c|c|c|c|c|c|}
\hline Author & $\begin{array}{l}\text { Sample } \\
\text { size }\end{array}$ & Intervention & $\begin{array}{l}\text { Length of } \\
\text { follow-up }\end{array}$ & $\begin{array}{l}\text { Primary } \\
\text { endpoint }\end{array}$ & Main secondary endpoints \\
\hline $\begin{array}{l}\text { Bochaton et al. } \\
2019 \text { [15] }\end{array}$ & 15 & $\begin{array}{c}\text { IABP } \\
\text { vs } \\
\text { IABP+ Impella } 5.0\end{array}$ & 1 month & $\begin{array}{l}\text { Cardiac power index } 12 \text { hours after } \\
\text { implantation }\end{array}$ & $\begin{array}{l}\text { Hemodynamic and metabolic variables over } \\
96 \text { hours; 30-day all-cause mortality; device-related } \\
\text { complications; LVEF at } 30 \text { days }\end{array}$ \\
\hline $\begin{array}{l}\text { Fuernau et al. } \\
2018 \text { [29] }\end{array}$ & 40 & $\begin{array}{c}\text { TTM at } 33^{\circ} \mathrm{C} \\
\text { vs } \\
\text { no TTM }\end{array}$ & 24 months & $\begin{array}{l}\text { Cardiac power index } 24 \text { hours after } \\
\text { randomization }\end{array}$ & $\begin{array}{l}\text { All-cause mortality } \\
\text { after } 30 \text { days, } 1 \text { year, and } 2 \text { years }\end{array}$ \\
\hline $\begin{array}{l}\text { Thiele et al. } \\
2017 \text { [13] }\end{array}$ & 686 & $\begin{array}{l}\text { Culprit PCI } \\
\text { vs } \\
\text { Multivessel PCI }\end{array}$ & 30 days & $\begin{array}{l}\text { Composite of death from any cause } \\
\text { or severe renal failure leading to } \\
\text { renal-replacement therapy within } \\
30 \text { days after randomization }\end{array}$ & $\begin{array}{l}\text { Individual components of the primary endpoint; } \\
\text { recurrent myocardial infarction; rehospitalization } \\
\text { for congestive heart failure; and repeat revascula- } \\
\text { rization }\end{array}$ \\
\hline $\begin{array}{l}\text { Pan et al. } 2017 \\
\text { [13] }\end{array}$ & 48 & $\begin{array}{l}\text { rhBNP } \\
\text { vs } \\
\text { no rhBNP }\end{array}$ & In-hospital & $\begin{array}{l}\text { Changes in PCWP from baseline to } \\
72 \text { hours after randomization }\end{array}$ & In-hospital mortality; cardiac index, urine output \\
\hline $\begin{array}{l}\text { Ouweneel et al. } \\
2017 \text { [13] }\end{array}$ & 48 & $\begin{array}{c}\text { IABP } \\
\text { vs } \\
\text { Impella CP }\end{array}$ & 6 months & 30-day all-cause mortality & 6-month mortality \\
\hline $\begin{array}{l}\text { Yan-yan et al. } \\
2016 \text { [13] }\end{array}$ & 60 & $\begin{array}{c}I A B P \\
v s \\
I A B P+\text { Shenfu }\end{array}$ & 6 months & All-cause mortality & Major adverse cardiac and cerebrovascular events \\
\hline $\begin{array}{l}\text { Barilla et al. } \\
2016[13]\end{array}$ & 58 & $\begin{array}{l}\text { Ivabradine } \\
\text { vs } \\
\text { no ivabradine }\end{array}$ & 6 months & $\begin{array}{l}\text { Change in NT-proBNP from baseline } \\
\text { to } 1 \text { week after randomization }\end{array}$ & $\begin{array}{l}\text { Cardiovascular death; hospital re-admission for } \\
\text { worsening heart failure; clinical and hemodynamic } \\
\text { improvement }\end{array}$ \\
\hline $\begin{array}{l}\text { Thiele et al. } \\
2012[13]\end{array}$ & 600 & $\begin{array}{l}\text { IABP } \\
\text { vs } \\
\text { no IABP }\end{array}$ & 30 days & 30-day all-cause mortality & $\begin{array}{l}\text { Serial assessments of serum lactate levels; cre- } \\
\text { atinine clearance; C-reactive protein levels; and } \\
\text { severity of disease as assessed with the use of the } \\
\text { Simplified Acute Physiology Score II }\end{array}$ \\
\hline $\begin{array}{l}\text { Tousek et al. } \\
2011[16]\end{array}$ & 80 & $\begin{array}{l}\text { Abciximab } \\
\text { vs } \\
\text { no abciximab }\end{array}$ & 30 days & $\begin{array}{l}\text { 30-day combined outcome } \\
\text { (death/reinfarction/stroke/new } \\
\text { severe renal failure) }\end{array}$ & Not reported \\
\hline $\begin{array}{l}\text { Prondzinsky et } \\
\text { al. } 2010 \text { [16] }\end{array}$ & 45 & $\begin{array}{l}\text { IABP } \\
\text { vs } \\
\text { no IABP }\end{array}$ & In-hospital & $\begin{array}{c}\text { Change in APACHE II scores from } \\
\text { baseline to } 4 \text { days after randomi- } \\
\text { zation }\end{array}$ & $\begin{array}{l}\text { Cardiac index; plasma brain natriuretic peptide; } \\
\text { and serum levels of interleukin- } 6\end{array}$ \\
\hline $\begin{array}{l}\text { Fuhrmann et al. } \\
2008[16]\end{array}$ & 32 & $\begin{array}{l}\text { Levosimendan } \\
\text { vs } \\
\text { Enoximone }\end{array}$ & 30 days & 30-day all-cause mortality & $\begin{array}{l}\text { Changes in invasively } \\
\text { measured hemodynamic variables during the first } \\
48 \text { hours }\end{array}$ \\
\hline $\begin{array}{l}\text { Seyfarth et al. } \\
2008[16]\end{array}$ & 26 & $\begin{array}{l}\text { Impella } \\
\text { vs } \\
\text { IABP }\end{array}$ & 30 days & $\begin{array}{c}\text { Change in the cardiac index from } \\
\text { baseline to } 30 \text { min after implan- } \\
\text { tation }\end{array}$ & $\begin{array}{l}\text { 30-day all-cause mortality; device-related compli- } \\
\text { cations included; and MODS and SOFA score after } \\
\qquad 30 \text { days }\end{array}$ \\
\hline $\begin{array}{l}\text { Alexander et al. } \\
2007[16]\end{array}$ & 398 & $\begin{array}{l}\text { Tilarginine } \\
\text { vs } \\
\text { Placebo }\end{array}$ & 6 months & $\begin{array}{l}\text { 30-day all-cause mortality (overall } \\
\text { and stratified by age) }\end{array}$ & $\begin{array}{l}\text { New York Heart Association functional class at } \\
30 \text { days, and 6-month mortality }\end{array}$ \\
\hline $\begin{array}{l}\text { Dzavik et al. } \\
2007[16]\end{array}$ & 79 & $\begin{array}{l}\text { NOS } \\
\text { vs } \\
\text { Placebo }\end{array}$ & 30 days & $\begin{array}{l}\text { Change in MAP from baseline to } \\
2 \text { hours after initiation of study drug }\end{array}$ & $\begin{array}{l}\text { Change in other hemodynamic variables at } \\
15 \text { minutes and } 2 \text { hours; overall } 30 \text {-day mortality }\end{array}$ \\
\hline $\begin{array}{l}\text { Jin-Long et al. } \\
2007[16]\end{array}$ & 39 & $\begin{array}{l}\text { Prolonged IABP vs } \\
\text { IABP }\end{array}$ & 12 months & Long-term left ventricular function & Exercise-capacity \\
\hline $\begin{array}{l}\text { Garcia-Gonzalez } \\
\text { et al. } 2006[16]\end{array}$ & 22 & $\begin{array}{l}\text { Levosimendan } \\
\text { vs } \\
\text { Dobutamine }\end{array}$ & Not reported & $\begin{array}{c}\text { Change in cardiac power from } \\
\text { baseline to } 24 \text { hours after initiation } \\
\text { of therapy }\end{array}$ & Not reported \\
\hline $\begin{array}{l}\text { Thiele et al. } \\
2005 \text { [16] }\end{array}$ & 41 & $\begin{array}{c}\text { IABP } \\
\text { vs } \\
\text { Tandem heart }\end{array}$ & 30 days & $\begin{array}{l}\text { Change in MAP from baseline to } \\
2 \text { hours after implantation }\end{array}$ & $\begin{array}{l}\text { All other hemodynamic and metabolic parameters; } \\
\qquad 30 \text {-day mortality }\end{array}$ \\
\hline $\begin{array}{l}\text { Hochman et al. } \\
1999[16]\end{array}$ & 302 & $\begin{array}{l}\text { Revasculariza- } \\
\text { tion vs } \\
\text { Medical treat- } \\
\text { ment }\end{array}$ & 1 year & 30-day all-cause mortality & Overall mortality 6 and 12 months after infarction \\
\hline $\begin{array}{l}\text { Urban et al. } \\
1999[16]\end{array}$ & 55 & $\begin{array}{c}\text { Acute CAG } \\
\text { vs } \\
\text { Initial medical } \\
\text { management }\end{array}$ & 30 days & $\begin{array}{l}\text { Primary pump failure within the } \\
\text { first } 48 \text { hours }\end{array}$ & \\
\hline
\end{tabular}

Abbreviations: APACHE, Acute Physiologic Assessment and Chronic Health Evaluation; BNP, brain natriuretic peptide; CAG, coronary angiograms; IABP, intra-aortic balloon pump; LVEF, left ventricular ejection fraction; MAP, mean arterial pressure; NT-proBNP, N-terminal prohormone BNP; PCl, percutaneous coronary intervention; PCWP, pulmonic-capillary wedge pressure; rhBNP, recombinant human BNP; TTM, targeted temperature management

lactate as a biochemical sign of hypoperfusion was used as an inclusion criterion in $5(26 \%)$ trials $[11,13,22,23$, 30]. A value of $>2 \mathrm{mmol} / \mathrm{l}$ was used in all 5 trials. In total $10(53 \%)$ trials mandated signs of circulatory impairment or reduced cardiac function [10, 15, 19, 20, 22, 24-27, 29], while the remaining trials did not use any criteria of hypoperfusion for inclusion. Low cardiac index (9 [47\%]) and reduced LVEF (3 [16\%]) were used as estimates of cardiac function. Cardiac index of $<2.2 \mathrm{l} / \mathrm{min} / \mathrm{m}^{2}$ was the most frequent limit for inclusion, however one trial used a limit of 
$<1.8 \mathrm{l} / \mathrm{min} / \mathrm{m}^{2}[24]$ and another trial used $<2.5 \mathrm{l} / \mathrm{min} / \mathrm{m}^{2}[26]$. Pulmonary capillary wedge pressure (PCWP) was used in $9(47 \%)$ trials $[10,15,20,22-24,26,27,29]$, and a cut-off value of $15 \mathrm{~mm} \mathrm{Hg}$ was used in $6(32 \%)$ trials whereas $18 \mathrm{~mm} \mathrm{Hg}$ was used in $3(16 \%)$ trials $[23,24,26]$. One trial had a pragmatic selection process, which included STEMI with $\mathrm{PCl}$ within 24 hours, inotropic drugs, and an intra-aortic balloon pump [16]. Only 6 (32\%) trials mandated both criteria for impaired cardiac function/low cardiac index and reduced end-organ perfusion [10, 15, 19, 20, 22, 26]. Overview of inclusion and exclusion criteria for each trial is presented in Table 2.

\section{Resuscitated out-of-hospital cardiac arrest in cardiogenic shock trials}

A total of $10(53 \%)$ trials included patients resuscitated from a cardiac arrest [10,11, 13, 17, 18, 20, 22, 24, 26, 29], $6(32 \%)$ trials did not report whereas only $3(16 \%)$ trials specifically excluded cardiac arrest patients $[16,23,30]$. Of the trials including cardiac arrest, the proportion of cardiac arrest patients were large ranging from $28 \%-91 \%[10,18]$.

\section{Outcomes}

Eight (42\%) trials used mortality as endpoints either as all-cause mortality rate alone $[10,11,15,18,24,26]$ or a combined endpoint where mortality was part of other variables $[13,17]$. Six $(32 \%)$ trials used measures of cardiac function at follow-up as the primary endpoint [16, 20, 21, 28-30], with cardiac index and cardiac power index being most frequent. Two (11\%) trials used mean arterial blood pressure as an endpoint $[22,27]$. One (5.3\%) trial used the change in left ventricular preload, measured as the PCWP [23]. One trial used NT-proB-type Natriuretic Peptide [25] and 1 trial used the change in Acute Physiologic Assessment and Chronic Health Evaluation (APACHE)-score [19].

\section{Ongoing trials}

The CS definitions used in future trials show a similar heterogeneity as the already published trials (Supplementary material, Tables S1-S2).

\section{DISCUSSION}

We described and summarized the definitions, inclusion criteria, and outcomes used in RCTs of CS. Furthermore, we assessed differences and similarities of trials regarding inclusion criteria, which relates to how researchers define CS. We report that inconsistencies of inclusion criteria across different trials exist. Furthermore, a similar pattern is seen in ongoing trials. This could increase the heterogeneity of trial populations between studies, thus making interstudy comparisons, including meta-analyses, difficult in addition to limiting external validity. This and a low level of evidence for CS treatment may partly explain the wide variation of care delivered to CS patients [30]. It would be advantageous to have uniform criteria for inclusion in future CS trials as well as having comparable outcomes.

\section{Blood pressure}

The most frequent inclusion criterion identified in this review was low systolic blood pressure, followed by different signs of peripheral hypoperfusion and reduced cardiac function (Figure 2). It is remarkable that blood pressure is the most frequent inclusion criterion in CS trials, since blood pressure is not part of the definition of CS $[7,8]$ in contemporary recommendations. On the contrary, patients can have hypoperfusion and reduced cardiac output without hypotension [32]. However, hypoperfusion is often associated with low blood pressure and blood pressure is an easily obtainable parameter that can be measured by non-physicians already prehospitally without the need for invasive catheters. Furthermore, low blood pressure has been shown to be a prognostic factor in CS, with lower blood pressure being associated with worse outcome [9]. Consequently, the Acute Cardiovascular Care Association's (ACVC) position statement for AMI-related CS has included hypotension (systolic blood pressure $<90 \mathrm{~mm} \mathrm{Hg}$ for $>30 \mathrm{~min}$ or use of vasopressors to maintain pressure $>90 \mathrm{~mm} \mathrm{Hg}$ during systole) as one of the criteria for CS [8]. It seems reasonable to use blood pressure as an inclusion criterion in CS trials, but research is needed to assess whether systolic, diastolic, or mean arterial blood pressure best reflects cardiovascular function. Low diastolic blood pressure can potentially be harmful and compromise coronary perfusion even with adequate systolic pressure [33].

\section{End-organ hypoperfusion}

Despite blood pressure being easily obtainable, a patient must fulfill other criteria such as tissue hypoperfusion to be considered in CS. Surprisingly, only 12 (63\%) trials included in this review had signs of hypoperfusion in the inclusion criteria. Tissue hypoperfusion is often defined by a clinical assessment of extremities, skin, urine output, and mental status, which are susceptible to subjective assessment by the treating physician. However, a biomarker of tissue hypoperfusion such as lactate concentration could propose an easily obtainable and more objective measure [34]. Furthermore, higher lactate concentrations have been shown to be a prognostic marker of poor outcome in CS [35]. The Association for Acute CardioVascular Care has included a plasma lactate concentration $>2.0 \mathrm{mmol} / \mathrm{l}$. Whether this is the optimal cut-off value is speculative. One previous study has shown mortality to drastically increase when lactate levels surpass $2.5 \mathrm{mmol} / \mathrm{l}$, which therefore may be a better cut-off value [35]. In our review, only 5 (26\%) trials used lactate as an inclusion criterion. IABP-SHOCK II used a less restrictive threshold of serum lactate of $>2 \mathrm{mmol} / \mathrm{I}$ compared to the ongoing DanGer-SHOCK, which excludes patients with $<2.5 \mathrm{mmol} / \mathrm{l}$. Moreover, one-third of the patients in the CULPRIT-SHOCK trial had a lactate level of $\leq 2 \mathrm{mmol} / \mathrm{l}$. These inconsistencies are of importance when comparing CS trials, since the included populations will potentially differ substantially in disease severity, and 
Table 2. Inclusion and exclusion criteria

\begin{tabular}{|c|c|c|c|}
\hline Author & Inclusion criteria & Exclusion criteria & $\begin{array}{l}\text { Including comatose } \\
\text { out-of-hospital car- } \\
\text { diac arrest patients? }\end{array}$ \\
\hline $\begin{array}{l}\text { Bochaton et al. } \\
2019 \text { [15] }\end{array}$ & $\begin{array}{l}\text { Blood pressure: } \\
\text { Cardiac function: } \\
\text { End-organ perfusion: } \\
- \\
\text { Other: } \\
\text { - STEMI } \\
\text { - Treated with primary angioplasty within } 24 \text { hours of the } \\
\text { index AMI, and } \\
\text { - Required inotropic drugs and an IABP }\end{array}$ & $\begin{array}{l}\text { - Resuscitation }>30 \text { min } \\
\text { - Aortic valvulopathy or mechanical valve } \\
\text { - Hypertrophic cardiopathy } \\
\text { - Left ventricular thrombus } \\
\text { - Refractory cardiogenic shock (INTERMACS } 1 \\
\text { or 2) } \\
\text { - Right ventricular failure } \\
\text { - Sepsis }\end{array}$ & No \\
\hline $\begin{array}{l}\text { Fuernau et al. } \\
2018 \text { [29] }\end{array}$ & $\begin{array}{l}\text { Blood pressure: } \\
\text { - Systolic blood pressure }<90 \mathrm{~mm} \mathrm{Hg} \text { for } \\
>30 \text { minutes or catecholamines required } \\
\text { Cardiac function: } \\
- \\
\text { End-organ perfusion: } \\
\text { At least } 1 \text { of the following: } \\
\text { - Altered mental status } \\
\text { - Cold, clammy skin and limbs } \\
\text { - Urine output }<30 \mathrm{ml} / \mathrm{h} \\
\text { - Arterial lactate }>2 \mathrm{mmol} / \mathrm{I} \\
\text { Other: } \\
\text { - Signs of pulmonary congestion }\end{array}$ & $\begin{array}{l}\text { - CS duration }>12 \text { hours } \\
\text { - Prior CPR with an indication for TTM treat- } \\
\text { ment }\end{array}$ & No \\
\hline $\begin{array}{l}\text { Thiele et al. } 2017 \\
\text { [13] }\end{array}$ & $\begin{array}{l}\text { Blood pressure: } \\
\text { - Systolic blood pressure }<90 \mathrm{~mm} \mathrm{Hg} \text { for } \\
>30 \text { minutes or catecholamines required } \\
\text { Cardiac function: } \\
- \\
\text { End-organ perfusion: } \\
\text { At least } 1 \text { of the following: } \\
\text { - Altered mental status } \\
\text { - Cold, clammy skin and limbs } \\
\text { - Urine output }<30 \mathrm{ml} / \mathrm{h} \\
\text { - Arterial lactate }>2 \mathrm{mmol} / \mathrm{l} \\
\text { Other: } \\
\text { - Signs of pulmonary congestion }\end{array}$ & $\begin{array}{l}\text { - Resuscitation }>30 \text { min } \\
\text { - No intrinsic heart action } \\
\text { - Expected severe deficit in cerebral function } \\
\text { - Indication for urgent CABG } \\
\text { - Mechanical cause of cardiogenic shock } \\
\text { - Single vessel disease } \\
\text { - CS duration }>12 \text { hours } \\
\text { - Age }>90 \text { years } \\
\text { - Massive pulmonary embolism } \\
\text { - Known severe renal insufficiency } \\
\text { - Life expectancy }<6 \text { months prior to admis- } \\
\text { sion }\end{array}$ & Yes \\
\hline $\begin{array}{l}\text { Pan et al. } 2017 \\
\text { [13] }\end{array}$ & $\begin{array}{l}\text { Blood pressure: } \\
\text { - Systolic blood pressure }<90 \mathrm{~mm} \mathrm{Hg} \text { for } \\
>30 \text { minutes or catecholamines required } \\
\text { Cardiac function: } \\
- \\
\text { End-organ perfusion: } \\
\text { At least } 1 \text { of the following: } \\
\text { - Altered mental status } \\
\text { - Cold, clammy skin and limbs } \\
\text { - Urine output }<30 \mathrm{ml} / \mathrm{h} \\
\text { - Arterial lactate }>2 \mathrm{mmol} / \mathrm{I} \\
\text { Other: } \\
\text { - Signs of pulmonary congestion }\end{array}$ & $\begin{array}{l}\text { - SBP }<90 \mathrm{~mm} \mathrm{Hg} \text { within first hour post-in- } \\
\text { tervention although } 12 \mathrm{mg} / \mathrm{kg} \times \text { min dopamine } \\
\text { and } 1: 1 \mathrm{IABP} \text { supporting } \\
\text { - PCWP }<18 \mathrm{~mm} \mathrm{Hg} \\
\text { - Inferior, posterior and right ventricle AMI } \\
\text { - Previous history of myocardial infarction; } \\
\text { - Previous electrocardiogram suggesting an } \\
\text { old myocardial infarction } \\
\text { - Previous history of chronic heart failure or } \\
\text { decreased LVEF } \\
\text { - Hypertrophic cardiomyopathy } \\
\text { - Severe valvular disease } \\
\text { - Estimated glomerular filtration rate }<15 \mathrm{ml} / \\
\text { min per } 1.73 \mathrm{~m}^{2} \\
\text { - Known intolerance history to rhBNP }\end{array}$ & No \\
\hline $\begin{array}{l}\text { Ouweneel et al. } \\
2017 \text { [13] }\end{array}$ & $\begin{array}{l}\text { Blood pressure: } \\
\text { - Systolic blood pressure }<90 \mathrm{~mm} \mathrm{Hg} \text { for } \\
>30 \text { minutes or catecholamines required } \\
\text { Cardiac function: } \\
- \\
\text { End-organ perfusion: } \\
- \\
\text { Other: } \\
\text { - Mechanical ventilation (To select a patient population } \\
\text { with even worse condition) }\end{array}$ & $\begin{array}{l}\text { - Severe aorto-iliac arterial disease impeding } \\
\text { placement of either IABP or percutaneous MCS } \\
\text { - Known severe cardiac aortic valvular disease } \\
\text { - Life expectancy }<12 \text { months } \\
\text { - CABG during the previous week }\end{array}$ & Yes \\
\hline $\begin{array}{l}\text { Yan-yan et al. } \\
2016 \text { [13] }\end{array}$ & $\begin{array}{l}\text { Blood pressure: } \\
\text { - Systolic blood pressure }<90 \mathrm{~mm} \mathrm{Hg} \text { for } \\
>30 \text { minutes or catecholamines required } \\
\text { Cardiac function: } \\
\text { - A reduction of cardiac index }<1.8 \mathrm{l} / \mathrm{min} / \mathrm{m}^{2} \\
\text { End-organ perfusion: } \\
- \\
\text { Other: } \\
-\mathrm{PCWP}>18 \mathrm{~mm} \mathrm{Hg}\end{array}$ & $\begin{array}{l}\text { - Severe valvular diseases } \\
\text { - Autoimmune diseases } \\
\text { - Infection } \\
\text { - Rheumatic activity } \\
\text { - Chronic liver disease } \\
\text { - Kidney disease } \\
\text { - Cancer } \\
\text { - Unable to be followed-up }\end{array}$ & Yes \\
\hline
\end{tabular}


Table 2. cont. Inclusion and exclusion criteria

\begin{tabular}{|c|c|c|c|}
\hline Author & Inclusion criteria & Exclusion criteria & $\begin{array}{l}\text { Including comatose } \\
\text { out-of-hospital car- } \\
\text { diac arrest patients? }\end{array}$ \\
\hline $\begin{array}{l}\text { Barilla et al. } 2016 \\
\text { [13] }\end{array}$ & $\begin{array}{l}\text { Blood pressure: } \\
\text { Systolic blood pressure }<100 \mathrm{~mm} \mathrm{Hg} \\
\text { Cardiac function: } \\
\text { LVEF }<40 \% \\
\text { End-organ perfusion: } \\
- \\
\text { Other: } \\
\text { - Sinus rhythm } \\
\text { - HR }>75 \text { beats/min }\end{array}$ & $\begin{array}{l}\text { - Atrial fibrillation } \\
\text { - II-III degree atrioventricular block }\end{array}$ & $\mathrm{n} / \mathrm{a}$ \\
\hline $\begin{array}{l}\text { Thiele et al. } 2012 \\
\text { [13] }\end{array}$ & $\begin{array}{l}\text { Blood pressure: } \\
\text { - Systolic blood pressure }<90 \mathrm{~mm} \mathrm{Hg} \text { for } \\
>30 \text { minutes or catecholamines required } \\
\text { Cardiac function: } \\
\text { - } \\
\text { End-organ perfusion: } \\
\text { At least } 1 \text { of the following: } \\
\text { - Altered mental status } \\
\text { - Cold, clammy skin and limbs } \\
\text { - Urine output }<30 \mathrm{ml} / \mathrm{h} \\
\text { - Arterial lactate }>2 \mathrm{mmol} / \mathrm{l} \\
\text { Other: } \\
\text { - Signs of pulmonary congestion }\end{array}$ & $\begin{array}{l}\text { - Resuscitation }>30 \text { min } \\
\text { - No intrinsic heart action } \\
\text { - Expected severe deficit in cerebral function } \\
\text { - Mechanical cause of shock } \\
\text { - Duration }>12 \text { hours } \\
\text { - Age }>90 \text { years } \\
\text { - Massive pulmonary embolism } \\
\text { - Severe peripheral artery disease precluding } \\
\text { IABP insertion } \\
\text { - Aortic regurgitation > grade II (on a scale of I } \\
\text { to IV, with higher grades indicating more severe } \\
\text { regurgitation); were older than } 90 \text { years of age } \\
\text { - Life expectancy }<6 \text { months prior to admis- } \\
\text { sion }\end{array}$ & Yes \\
\hline $\begin{array}{l}\text { Tousek et al. } 2011 \\
{[16]}\end{array}$ & $\begin{array}{l}\text { At least } 1 \text { of the following: } \\
\text { Blood pressure: } \\
\text { - Systolic blood pressure }<90 \mathrm{~mm} \mathrm{Hg} \text { and heart rate }>90 \\
\text { beats/min } \\
\text { - Catecholamine support to maintain systolic blood } \\
\text { pressure }>90 \mathrm{~mm} \mathrm{Hg} \\
\text { Cardiac function: } \\
\text { - } \\
\text { End-organ perfusion: } \\
\text { - Cold, wet, sweating skin, and } \\
\text { heart rate }>90 \text { beats/min } \\
\text { Other: } \\
\text { - }\end{array}$ & $\begin{array}{l}\text { - Contraindications for the use of abciximab } \\
\text { - Severe valvular disease } \\
\text { - Mechanical cause of shock } \\
\text { - } 10000 \mathrm{IU} \text { of heparin in the previous } 6 \mathrm{~h} \\
\text { - No indication for PCI }\end{array}$ & Yes \\
\hline $\begin{array}{l}\text { Prondzinsky et al. } \\
2010[16]\end{array}$ & $\begin{array}{l}\text { End-organ perfusion criteria }+ \text { at least } 1 \text { of the following: } \\
\text { Blood pressure: } \\
\text { - Systolic blood pressure }<90 \mathrm{~mm} \mathrm{Hg} \text { for } \\
>30 \text { minutes or catecholamines required } \\
\text { Cardiac function: } \\
\text { - Cardiac index } \leq 2.2 \mathrm{l} / \mathrm{min} / \mathrm{m}^{2} \\
\text { End-organ perfusion: } \\
\text { At least } 1 \text { of the following: } \\
\text { - Cool extremities } \\
\text { - Oliguria } \\
\text { Other: } \\
\text { - }\end{array}$ & $\begin{array}{l}\text { - Severe peripheral artery disease precluding } \\
\text { IABP insertion } \\
\text { - Mechanical cause of CS } \\
\text { - Severe valvular disease }\end{array}$ & $\mathrm{n} / \mathrm{a}$ \\
\hline $\begin{array}{l}\text { Fuhrmann et al. } \\
2008[16]\end{array}$ & $\begin{array}{l}\text { Blood pressure: } \\
\text { - Systolic blood pressure }<90 \mathrm{~mm} \mathrm{Hg} \text { for } \\
>30 \text { minutes or catecholamines required } \\
\text { Cardiac function: } \\
\text { - Cardiac index }<2.5 \mathrm{l} / \mathrm{min} / \mathrm{m}^{2} \\
\text { End-organ perfusion: } \\
\text { At least } 1 \text { of the following: } \\
\text { - Altered mental status } \\
\text { - Cold, clammy skin and limbs } \\
\text { - Urine output }<30 \mathrm{ml} / \mathrm{h} \\
\text { Other: } \\
\text { - PCWP }>18 \mathrm{~mm} \mathrm{Hg}\end{array}$ & $\begin{array}{l}\text { - Duration of CS }>24 \text { hours } \\
\text { - Mechanical cause of CS } \\
\text { - Severe valvular disease } \\
\text { - Sustained VT } \\
\text { - Major bleeding } \\
\text { - Severe hepatic failure } \\
\text { - Sepsis }\end{array}$ & Yes \\
\hline $\begin{array}{l}\text { Seyfarth et al. } \\
2008 \text { [16] }\end{array}$ & $\begin{array}{l}\text { Blood pressure: } \\
\text { - Systolic blood pressure }<90 \mathrm{~mm} \mathrm{Hg} \text { for } \\
>30 \text { minutes or catecholamines required } \\
\text { Cardiac function: } \\
\text { At least } 1 \text { of the following: } \\
\text { - Cardiac index }<2.2 \mathrm{l} / \mathrm{min} / \mathrm{m}^{2}+\mathrm{PCWP}>15 \mathrm{~mm} \mathrm{Hg} \\
\text { - LVEF }<30 \%+\mathrm{LV} \text { end-diastolic pressure }<30 \mathrm{~mm} \mathrm{Hg} \\
\text { End-organ perfusion: } \\
\text { At least } 1 \text { of the following: } \\
\text { - Cold, clammy skin and limbs } \\
\text { - Urine output }<30 \mathrm{ml} / \mathrm{h} \\
\text { Other: } \\
\text { - Heart rate }>60 \text { beats } / \mathrm{min}\end{array}$ & $\begin{array}{l}\text { - Duration of CS }>24 \text { hours } \\
\text { - Resuscitation }>30 \text { minutes } \\
\text { - Mechanical cause of CS } \\
\text { - Predominant RV failure } \\
\text { - Massive pulmonary embolism } \\
\text { - Severe valvular disease } \\
\text { - Sepsis } \\
\text { - Known cerebral disease } \\
\text { - Thrombus in the LV } \\
\text { - Hypertrophic obstructive cardiomyopathy }\end{array}$ & Yes \\
\hline
\end{tabular}


Table 2. cont. Inclusion and exclusion criteria

\begin{tabular}{|c|c|c|c|}
\hline Author & Inclusion criteria & Exclusion criteria & $\begin{array}{l}\text { Including comatose } \\
\text { out-of-hospital car- } \\
\text { diac arrest patients? }\end{array}$ \\
\hline $\begin{array}{l}\text { Alexander et al. } \\
2007 \text { [16] }\end{array}$ & $\begin{array}{l}\text { Blood pressure: } \\
\text { - Systolic blood pressure }<100 \mathrm{~mm} \mathrm{Hg} \text { despite } \\
\text { vasopressor therapy for more than } 1 \text { hour } \\
\text { Cardiac function: } \\
\text { - LVEF }<40 \% \\
\text { End-organ perfusion: } \\
\text { - Mandatory but not specified } \\
\text { Other: } \\
\text { - Clinical or hemodynamic evidence of elevated left } \\
\text { ventricular filling pressures }\end{array}$ & $\begin{array}{l}\text { - Duration of CS }>24 \text { hours } \\
\text { - Mechanical cause of shock } \\
\text { - Indication for acute CABG } \\
\text { - Severe valvular disease } \\
\text { - Predominant RV failure } \\
\text { - End-stage renal disease } \\
\text { - Acute respiratory distress syndrome } \\
\text { - Severe cerebral damage precluding survival } \\
\text { - Recent thoracic or abdominal surgery } \\
\text { - Primary pulmonary hypertension } \\
\text { - Infection }\end{array}$ & $\mathrm{n} / \mathrm{a}$ \\
\hline $\begin{array}{l}\text { Dzavik et al. } 2007 \\
\text { [16] }\end{array}$ & $\begin{array}{l}\text { Blood pressure: } \\
\text { - Systolic blood pressure }<100 \mathrm{~mm} \text { Hg despite } \\
\text { vasopressor therapy } \\
\text { Cardiac function: } \\
\text { - Cardiac index }<2.2 \mathrm{l} / \mathrm{min} / \mathrm{m}^{2} \text { if measured off IABP, or }<2.5 \\
\mathrm{l} / \mathrm{min} / \mathrm{m}^{2} \text { on } \\
\text { End-organ perfusion: } \\
- \\
\text { Other: } \\
-\mathrm{PCWP}>15 \mathrm{~mm} \mathrm{Hg}\end{array}$ & $\begin{array}{l}\text { - Mechanical cause of CS } \\
\text { - Severe valvular disease } \\
\text { - Predominant RV failure } \\
\text { - Sepsis } \\
\text { - Major bleeding } \\
\text { - Preterminal profound shock } \\
\text { - Anoxic brain damage } \\
\text { - Primary pulmonary hypertension } \\
\text { - Life expectancy }<6 \text { months prior to admis- } \\
\text { sion }\end{array}$ & $\mathrm{n} / \mathrm{a}$ \\
\hline $\begin{array}{l}\text { Jin-Long et al. } \\
2007 \text { [16] }\end{array}$ & $\begin{array}{l}\text { Blood pressure: } \\
\text { - Systolic blood pressure }<80 \mathrm{~mm} \mathrm{Hg} \text { or }>20 \% \text { reduction } \\
\text { from baseline } \\
\text { Cardiac function: } \\
\text { - } \\
\text { End-organ perfusion: } \\
\text { - Peripheral cyanosis } \\
\text { - Oliguria } \\
\text { - Cold extremities } \\
\text { Other: } \\
\text { - }\end{array}$ & None mentioned & $\mathrm{n} / \mathrm{a}$ \\
\hline $\begin{array}{l}\text { Garcia-Gonzalez } \\
\text { et al. } 2006 \text { [16] }\end{array}$ & $\mathrm{n} / \mathrm{a}$ & $\begin{array}{l}\text { - Mechanical cause of CS } \\
\text { - Severe valvular disease } \\
\text { - Predominantly RV failure } \\
\text { - Sustained VT } \\
\text { - Stroke within last } 3 \text { months } \\
\text { - Il or III atrioventricular block } \\
\text { - End-stage renal failure } \\
\text { - Severe liver disease } \\
\text { - Acute respiratory distress syndrome } \\
\text { - Sepsis }\end{array}$ & $\mathrm{n} / \mathrm{a}$ \\
\hline $\begin{array}{l}\text { Thiele et al. } 2005 \\
\text { [16] }\end{array}$ & $\begin{array}{l}\text { Blood pressure: } \\
\text { - Systolic blood pressure }<90 \mathrm{~mm} \mathrm{Hg} \text { for } \\
>30 \text { minutes or catecholamines required } \\
\text { Cardiac function: } \\
\text { - Cardiac index }<2.1 \mathrm{l} / \mathrm{min} / \mathrm{m}^{2} \\
\text { End-organ perfusion: } \\
\text { At least } 1 \text { of the following: } \\
\text { - Altered mental status } \\
\text { - Cold, clammy skin and limbs } \\
\text { - Urine output }<30 \mathrm{ml} / \mathrm{h} \\
\text { - Arterial lactate }>2 \mathrm{mmol} / \mathrm{l} \\
\text { Other: } \\
\text { - PCWP }>15 \mathrm{~mm} \mathrm{Hg}\end{array}$ & $\begin{array}{l}\text { Resuscitation }>30 \text { minutes } \\
\text { - Duration }>12 \text { hours } \\
\text { - Mechanical cause of CS } \\
\text { - Right ventricular failure } \\
\text { - Age }>75 \text { years } \\
\text { - Sepsis } \\
\text { - Severe aortic regurgitation } \\
\text { - Severe cerebral damage } \\
\text { - Severe peripheral vascular disease } \\
\text { - Diseases with reduced life expectancy }\end{array}$ & Yes \\
\hline $\begin{array}{l}\text { Hochman et al. } \\
1999 \text { [16] }\end{array}$ & $\begin{array}{l}\text { Blood pressure: } \\
\text { - Systolic blood pressure }<90 \mathrm{~mm} \mathrm{Hg} \text { for } \\
>30 \text { minutes or catecholamines required } \\
\text { Cardiac function: } \\
\text { - Cardiac index }<2.2 \mathrm{l} / \mathrm{min} / \mathrm{m}^{2} \\
\text { End-organ perfusion: } \\
\text { At least } 1 \text { of the following: } \\
\text { - Cold, clammy skin and limbs } \\
\text { - Urine output }<30 \mathrm{ml} / \mathrm{h} \\
\text { Other: } \\
\text { - Heart rate }>60 \text { beats } / \mathrm{min} \\
\text { - PCWP }>15 \mathrm{~mm} \mathrm{Hg}\end{array}$ & $\begin{array}{l}\text { - Duration of CS }>12 \text { hours } \\
\text { - Mechanical cause of CS } \\
\text { - Severe valvular disease } \\
\text { - Dilated cardiomyopathy }\end{array}$ & Yes \\
\hline $\begin{array}{l}\text { Urban et al. } 1999 \\
\text { [16] }\end{array}$ & $\begin{array}{l}\text { Blood pressure: } \\
\text { - Systolic blood pressure }<90 \mathrm{~mm} \mathrm{Hg} \text { or catecholamines } \\
\text { required } \\
\text { Cardiac function: } \\
\text { - Cardiac index }<2.2 \mathrm{l} / \mathrm{min} / \mathrm{m}^{2} \\
\text { End-organ perfusion: } \\
\text { - } \\
\text { Other: } \\
-\mathrm{PCWP}>15 \mathrm{~mm} \mathrm{Hg}\end{array}$ & $\begin{array}{l}\text { - Mechanical cause of CS } \\
\text { - Severe valvular disease } \\
\text { - Ongoing CPR } \\
\text { - Expected severe deficit in cerebral function } \\
\text { - Serious non-cardiac disease }\end{array}$ & Yes \\
\hline
\end{tabular}

Abbreviations: AMI, acute myocardial infarction; CABG, coronary artery bypass graft; CPR, cardiopulmonary resuscitation; CS, cardiogenic shock; LV, left ventricle; $M C S$, mechanical circulatory support; RV, right ventricle; SBP, systolic blood pressure; STEMI, ST-segment elevation myocardial infarction; TTM, targeted temperature management; VT, ventricular tachycardia; other — see Table 1 
Table 3. Cohort characteristics

\begin{tabular}{|c|c|c|c|c|c|c|c|c|c|c|c|c|c|}
\hline Author & $\begin{array}{l}\text { Age, } \\
\text { years }\end{array}$ & $\begin{array}{c}\text { Blood } \\
\text { pressure, } \\
\text { mm Hg }\end{array}$ & $\begin{array}{l}\text { Heart } \\
\text { rate, } \\
\text { bpm }\end{array}$ & $\begin{array}{l}\text { Pro- } \\
\text { portion } \\
\text { resuscita- } \\
\text { ted from } \\
\text { CA, \% }\end{array}$ & $\begin{array}{l}\text { Propor- } \\
\text { tion of } \\
\text { mechani- } \\
\text { cal venti- } \\
\text { lation, \% }\end{array}$ & $\begin{array}{c}\text { STEMI, } \\
\%\end{array}$ & $\begin{array}{c}\text { LVEF, } \\
\%\end{array}$ & $\begin{array}{c}\text { Cardiac } \\
\text { Index, \% }\end{array}$ & $\begin{array}{c}\text { PCWP, } \\
\%\end{array}$ & $\begin{array}{c}\text { CVP, } \\
\%\end{array}$ & $\begin{array}{c}\text { Lac- } \\
\text { tate, } \\
\%\end{array}$ & $\begin{array}{c}\text { Mor- } \\
\text { tality, } \\
\%\end{array}$ & $\begin{array}{c}\text { Death } \\
\text { of } \\
\text { hypoxic } \\
\text { brain } \\
\text { injury, } \%\end{array}$ \\
\hline $\begin{array}{l}\text { Bochaton et al. } \\
2019 \text { [15] }\end{array}$ & 57 & 69 (MAP) & 101 & 0 & 31 & $n / a$ & 30 & 2.3 & 16 & 10 & 1.5 & 15 & $n / a$ \\
\hline $\begin{array}{l}\text { Fuernau et al. } \\
2018 \text { [29] }\end{array}$ & 76 & 84 (SBP) & $n / a$ & 0 & 100 & 52 & $n / a$ & $\mathrm{n} / \mathrm{a}$ & $\mathrm{n} / \mathrm{a}$ & $\mathrm{n} / \mathrm{a}$ & 3.4 & 55 & $\mathrm{n} / \mathrm{a}$ \\
\hline $\begin{array}{l}\text { Thiele et al. } \\
2017 \text { [13] }\end{array}$ & 70 & 100 (SBP) & 91 & 54 & 81 & 62 & 31 & $n / a$ & $n / a$ & $\mathrm{n} / \mathrm{a}$ & 5.0 & 47 & 11 \\
\hline $\begin{array}{l}\text { Pan et al. } \\
2017 \text { [13] }\end{array}$ & 64 & 104 & 98 & 0 & $n / a$ & 100 & 39 & 1.7 & 27 & $\mathrm{n} / \mathrm{a}$ & $\mathrm{n} / \mathrm{a}$ & 33 & 0 \\
\hline $\begin{array}{l}\text { Ouweneel et al. } \\
2017 \text { [13] }\end{array}$ & 58 & 82 (SBP) & 82 & 91 & 100 & 100 & 46 & $\mathrm{n} / \mathrm{a}$ & $n / a$ & $\mathrm{n} / \mathrm{a}$ & 8.2 & 48 & 23 \\
\hline $\begin{array}{l}\text { Yan-yan et al. } \\
2016 \text { [13] }\end{array}$ & 58 & 77 (SBP) & $\mathrm{n} / \mathrm{a}$ & $\mathrm{n} / \mathrm{a}$ & $n / a$ & 100 & 45 & $\mathrm{n} / \mathrm{a}$ & $\mathrm{n} / \mathrm{a}$ & $\mathrm{n} / \mathrm{a}$ & $\mathrm{n} / \mathrm{a}$ & 8.3 & $\mathrm{n} / \mathrm{a}$ \\
\hline $\begin{array}{l}\text { Barilla et al. } \\
2016 \text { [13] }\end{array}$ & 55 & 84 (SBP) & 96 & $n / a$ & 38 & 100 & 34 & $\mathrm{n} / \mathrm{a}$ & $n / a$ & $\mathrm{n} / \mathrm{a}$ & $\mathrm{n} / \mathrm{a}$ & 10 & 0 \\
\hline $\begin{array}{l}\text { Thiele et al. } \\
2012 \text { [13] }\end{array}$ & 70 & 90 (SBP) & 92 & 45 & 82 & 69 & 35 & $\mathrm{n} / \mathrm{a}$ & $\mathrm{n} / \mathrm{a}$ & $\mathrm{n} / \mathrm{a}$ & 4.2 & 41 & $n / a$ \\
\hline $\begin{array}{l}\text { Tousek et al. } \\
2011 \text { [16] }\end{array}$ & 66 & 97 (SBP) & 90 & 25 & 46 & 75 & $n / a$ & $n / a$ & $n / a$ & $\mathrm{n} / \mathrm{a}$ & $\mathrm{n} / \mathrm{a}$ & 30 & $n / a$ \\
\hline $\begin{array}{l}\text { Prondzinsky et } \\
\text { al. } 2010 \text { [16] }\end{array}$ & 64 & $\mathrm{n} / \mathrm{a}$ & $n / a$ & $\mathrm{n} / \mathrm{a}$ & 52 & 64 & 38 & 2 & 18 & $\mathrm{n} / \mathrm{a}$ & $\mathrm{n} / \mathrm{a}$ & 33 & $n / a$ \\
\hline $\begin{array}{l}\text { Fuhrmann et al. } \\
2008 \text { [16] }\end{array}$ & 68 & 69 (MAP) & 105 & 62 & 87 & 84 & 24 & 2.2 & 21 & $\mathrm{n} / \mathrm{a}$ & 5.4 & 53 & 0 \\
\hline $\begin{array}{l}\text { Seyfarth et al. } \\
2008 \text { [16] }\end{array}$ & 66 & 103 (SBP) & 96 & 77 & 92 & 0 & 27 & 1.7 & 22 & $\mathrm{n} / \mathrm{a}$ & 6.5 & 46 & $\mathrm{n} / \mathrm{a}$ \\
\hline $\begin{array}{l}\text { Alexander et al. } \\
2007 \text { [16] }\end{array}$ & 67 & 88 (SBP) & $n / a$ & $n / a$ & 86 & 77 & 27 & $\mathrm{n} / \mathrm{a}$ & $n / a$ & $\mathrm{n} / \mathrm{a}$ & $\mathrm{n} / \mathrm{a}$ & 45 & $n / a$ \\
\hline $\begin{array}{l}\text { Dzavik et al. } \\
2007 \text { [16] }\end{array}$ & 69 & 71 (SBP) & 90 & $n / a$ & $n / a$ & $n / a$ & 27 & 1.7 & 22 & $\mathrm{n} / \mathrm{a}$ & $\mathrm{n} / \mathrm{a}$ & 39 & $n / a$ \\
\hline $\begin{array}{l}\text { Jin-Long et al. } \\
2007 \text { [16] }\end{array}$ & 66 & 77 (SBP) & 115 & $\mathrm{n} / \mathrm{a}$ & $n / a$ & $\mathrm{n} / \mathrm{a}$ & 30 & 2 & 27 & $\mathrm{n} / \mathrm{a}$ & $\mathrm{n} / \mathrm{a}$ & $\mathrm{n} / \mathrm{a}$ & $\mathrm{n} / \mathrm{a}$ \\
\hline $\begin{array}{l}\text { Garcia-Gonzalez } \\
\text { et al. } 2006 \text { [16] }\end{array}$ & 64 & 76 (MAP) & 85 & $n / a$ & $\mathrm{n} / \mathrm{a}$ & 100 & 29 & 1.7 & 26 & $\mathrm{n} / \mathrm{a}$ & $\mathrm{n} / \mathrm{a}$ & $n / a$ & $n / a$ \\
\hline $\begin{array}{l}\text { Thiele et al. } \\
2005 \text { [16] }\end{array}$ & 64 & 64 (MAP) & 117 & 54 & 98 & $n / a$ & 27 & 1.6 & 24 & 12 & 4.2 & 44 & $n / a$ \\
\hline $\begin{array}{l}\text { Hochman et al. } \\
1999 \text { [16] }\end{array}$ & 66 & 88 (SBP) & 101 & 28 & $\mathrm{n} / \mathrm{a}$ & $n / a$ & 31 & 1.7 & 24 & $\mathrm{n} / \mathrm{a}$ & $\mathrm{n} / \mathrm{a}$ & 51 & $\mathrm{n} / \mathrm{a}$ \\
\hline $\begin{array}{l}\text { Urban et al. } \\
1999 \text { [16] }\end{array}$ & 65 & 77 & 103 & 31 & 54 & 80 & $\mathrm{n} / \mathrm{a}$ & 1.7 & 24 & $\mathrm{n} / \mathrm{a}$ & 7.7 & 73 & $n / a$ \\
\hline
\end{tabular}

Abbreviations: CA, cardiac arrest; CVP, central venous pressure; LVEF, left ventricular ejection fraction; MAP, mean arterial pressure; SBP, systolic blood pressure; STEMI, ST-segment elevation myocardial infarction; other: see Table 1 and 2

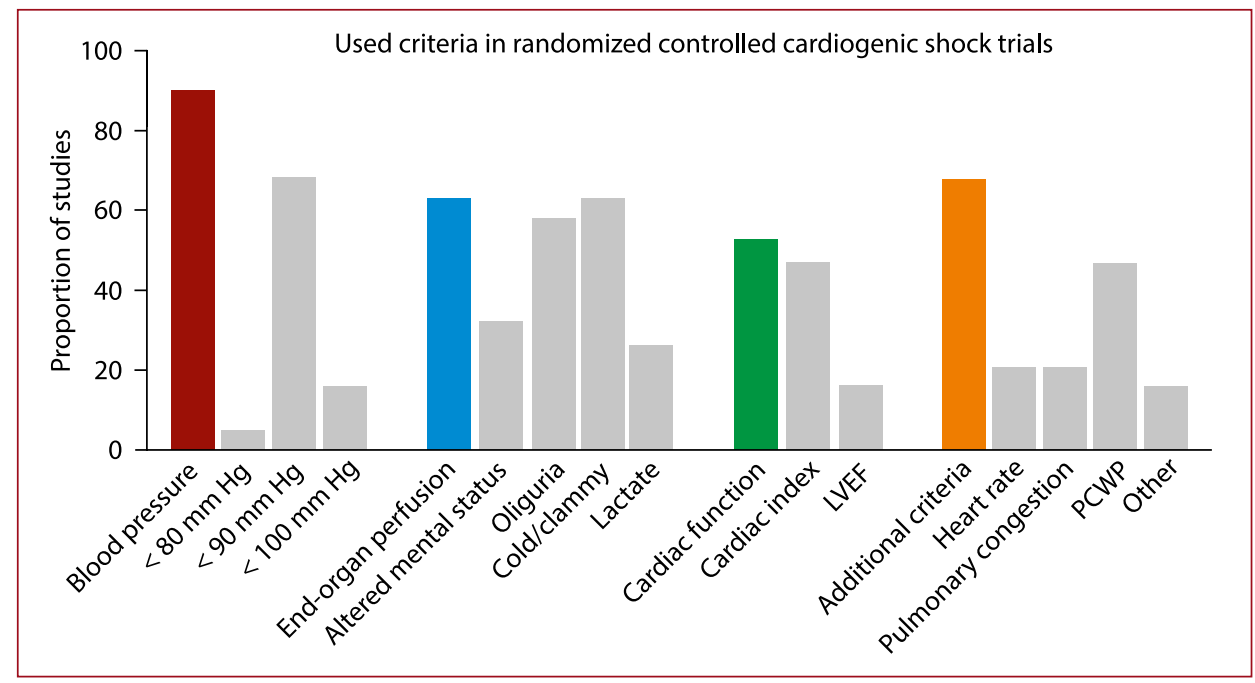

Figure 2. Bar chart depicting proportions of existing trials using different overall inclusion criteria (red, blue, green, and orange columns) and sub-criteria (grey columns) in the definition of cardiogenic shock

Abbreviations: LVEF, left ventricular ejection fraction; PCWP, pulmonic-capillary wedge pressure 
possibly extrapolation of results from one trial may be limited $[11,13,36]$.

\section{Assessment of cardiac output and cardiac function in the CS-definition}

Per definition, true CS represents an extreme degree of acute heart failure whereby cardiac output is insufficient to meet basic metabolic requirements. These organ-level perturbations may occur at different levels of cardiac output, which varies from individual to individual [37]. As such, no universal cardiac output cut-off can be used to define CS from a theoretical point of view. Furthermore, it has been proven difficult to relate low cardiac output with poor outcomes in critically ill patients $[40,41]$. In this review, eight trials used cardiac index to include patients, and values varied from $<1.8 \mathrm{l} / \mathrm{min} / \mathrm{m}^{2}$ [24] to $<2.5 \mathrm{l} / \mathrm{min} / \mathrm{m}^{2}$ [26]. When including patients with hyperacute, severe illness in trials it may, however, be difficult to obtain a valid measure of cardiac output prior to randomization if an invasive procedure is needed [40].

An alternative measure of cardiac performance is an echocardiographic assessment. Three (16\%) trials in this review used LVEF to include patients. Two trials used LVEF $<40 \%[15,25]$ and one trial used LVEF $<30 \%$ [20]. Echocardiography has several advantages, being easily accessible, if trained personnel are present, and not having the adverse effects of an invasive procedure. Echocardiography should be performed in all patients with suspected CS and AMI for rapid assessment of differential diagnoses and rule-out of mechanical complications [8]. LV dysfunction is a marker of CS, whereas small heart cavities with normal function may suggest hypovolemic shock. It may, therefore, be problematic to consider a patient for a CS trial without echocardiographic evidence of reduced cardiac function. However, the optimal cut-off value of LVEF is unknown.

There are several limitations to LVEF and cardiac index as estimates of cardiac function. In dilated hearts, stroke volume and cardiac output may be normal despite reduced LVEF, and further LVEF is often unprecise, especially when estimating LVEF in bedridden, intubated patients. Only $6(32 \%)$ trials had defined requirements for both inadequate tissue perfusion and low cardiac output/impaired cardiac function. Lastly, CS can be caused by predominantly RV failure, which has previously been shown to be the primary cause of CS of approximately $7 \%$ of the patients [41]. In such cases echocardiographic assessment of RV function plays a key role, as the typical sign of LV failure usually is absent.

\section{Pulmonary capillary wedge pressure}

The cardiac index can be reduced because of insufficient preload when filling pressures are low despite preserved cardiac function. Thus, hypovolemia is a differential diagnosis to CS. Therefore, adequate filling of the failing ventricle is required for the diagnosis of CS. If PCWP is low, $\mathrm{CS}$ is unlikely unless caused by right heart failure [42]. When
PCWP is elevated, it is an estimate of backward LV failure, thus giving an index of poor LV function. In this review, 9 trials used elevated PCWP ( $>15 \mathrm{~mm} \mathrm{Hg}$ or $>18 \mathrm{~mm} \mathrm{Hg}$ ) as an inclusion criterion, and 1 trial used low/normal PCWP $(<18 \mathrm{~mm} \mathrm{Hg})$ as an exclusion criterion. A PCWP $>15 \mathrm{~mm} \mathrm{Hg}$ in the supine position is used by guidelines as a diagnostic for left-sided heart failure. This corresponds to a value of $2 \mathrm{~mm} \mathrm{Hg}$ higher than the $98^{\text {th }}$ percentile of the healthy [43]. Yet, PCWP in heart failure has a poor negative predictive value (52\%), because PCWP is often elevated only during exercise in chronic heart failure [44]. In this context, it is meaningful to use low PCWP to exclude CS. However, high PCWP is not necessarily associated with CS and is a highly invasive technique.

\section{Outcomes}

The outcomes of patients included in trials as well as the outcomes definitions and endpoints differ significantly between trials. Most frequently, all-cause mortality was used, which is a robust endpoint but limited to larger trials with sufficient power. Since CS patients are rare compared to for example myocardial infarction patients, it is to be expected that some trials use other outcome measures than mortality, which enables smaller sample sizes. Underlining the point, that CS trials lacks comparability, it is striking that multiple different hemodynamic endpoints have been chosen in different trials. Cardiac index, cardiac power index, as well as blood pressure, change in ventricular preload, PCWP, and biomarkers have all been used as endpoints. A discussion and consensus among experts regarding relevant endpoints should be published for the guidance of future trialists. So far no discussion of outcomes has been made in published consensus documents [8].

\section{What to do with CS patients with cardiac arrest?}

CS frequently occur together with cardiac arrest due to shared etiology, being acute or chronic myocardial injury. Comatose patients successfully resuscitated from a cardiac arrest often require vasopressors to maintain blood pressure, have decreased urine output (acute kidney injury), have cold skin/extremities (targeted temperature management), have markedly elevated lactate levels due to cessation of circulation, and have reduced myocardial function with low cardiac output and reduced LVEF (myocardial stunning) [38, 45]. Therefore, a large proportion of resuscitated cardiac arrest patients fulfill the criteria used in CS trials [12] and this may explain the large proportion of cardiac arrest patients in the CS trials, which we found in this review.

However, low blood pressure in cardiac arrest is often a consequence of vasoplegia due to systemic inflammation, and not always a consequence of low cardiac output [46]. Cardiac arrest and CS also often differ regarding sequelae (i.e., anoxic brain injury vs multisystem organ failure) and anoxic brain injury is unlikely to improve with cardiovascular therapies. 
In the trial by Thiele et al. [11], 598 CS patients were randomized to receive Intraaortic Balloon Pump vs control. Almost half were resuscitated from cardiac arrest. Overall, the use of an Intraaortic Balloon Pump did not improve outcome. However, a subgroup-analyses showed that the point estimate for mortality of the intervention showed numeric divergent results when stratified for the presence of cardiac arrest. This interaction was not statistically significant, though. However, the findings highlight the need for a discussion of whether to include cardiac arrest patients in CS trials. At least, analyses stratifying for cardiac arrest should be performed. Surprisingly, in this review, eight trials did not even report whether they included patients resuscitated from cardiac arrest.

Another important issue to consider when including cardiac arrest-patient in CS trials, is whether the patient is expected to recover neurologically. Therefore, cardiac arrest patients with early signs of poor prognosis, such as a long time to ROSC or non-shockable primary rhythm, should be considered excluded for CS trials [47].

\section{Where to go from here?}

Future CS trials should use uniform inclusion criteria based on consensus by a relevant international group of experts in the field, including relevant measures of acute LV and RV dysfunction and tissue hypoperfusion and particularly consensus of whether to include patients resuscitated from cardiac arrest, would be of value. Furthermore, a relevant measure to exclude patients in hypovolemic shock should be determined. Assessing PCWP with an invasive approach is one possibility, however, research in the acute setting cannot wait for the insertion of a pulmonary artery catheter, which is time-consuming and has not been shown to improve outcomes in shock [48]. Signs of pulmonary congestion, such as rales or a chest X-ray with pulmonary edema could be alternatives, as well as echocardiographic measures of elevated LV preload. Tissue hypoperfusion with at least one of the following: altered mental status, cold, clammy skin, or low urine output combined with increased arterial lactate (possibly $>2.5 \mathrm{mmol} / \mathrm{l}$ ). Low blood pressure can be used to raise suspicion of CS, but the optimal cut-off has not been determined. Specific cut-off values should be discussed internationally, and consensus guidelines should be published in order to increase comparability of future CS trials. The number of cardiac arrest patients included should be reported, and subgroup analyses on this group performed.

In septic shock, which is equally difficult to define, a data-driven approach has been undertaken and a possible septic shock definition with clinical criteria was generated through meetings, Delphi processes, and voting, followed by feedback from international professional societies [49]. Inspired by the current septic shock definition, a more pragmatic approach in CS RCTs could leave out invasive signs of reduced cardiac function and include all patients with AMI and signs of hypoperfusion (vasopressor require- ments and elevated lactate). In this case, it is assumed that AMI-patients with shock most frequently have cardiogenic shock, but this approach will likely result in the inclusion of non-cardiogenic shock patients. However, a brief and focused transthoracic echocardiographic examination could quickly rule in or rule out a cardiac etiology and should be mandatory in every case where acute heart failure is suspected.

\section{CONCLUSIONS}

In conclusion, significant heterogeneity of inclusion criteria exists between CS trials. Differences are mainly related to objective measures of cardiac function such as LVEF or cardiac index and whether to include comatose patients after cardiac arrest. Uniform inclusion criteria in the future would be beneficial for interstudy comparisons, and we suggest an international consensus of overall CS enrolment criteria for future trials.

\section{Supplementary material}

Supplementary material is available at https://journals. viamedica.pl/kardiologia_polska.

\section{Article information}

Conflict of interest: AP receives grant support from the Novo Nordisk Foundation and Pfizer. JEM receives grant support from Abiomed and speakers fee Orion Pharma and Abiomed. The remaining authors report no conflicts of interest.

Funding: The study was funded by The Danish Heart Foundation (18-R125-A8472-22085) and the Lundbeck Foundation (R186-20152132). None of the funders had any influence on any aspects of the current study.

Open access: This article is available in open access under Creative Common Attribution-Non-Commercial-No Derivatives 4.0 International (CC BY-NC-ND 4.0) license, allowing to download articles and share them with others as long as they credit the authors and the publisher, but without permission to change them in any way or use them commercially. For commercial use, please contact the journal office at kardiologiapolska@ptkardio.pl.

How to cite: Josiassen J, Frydland M, Hassager C, et al. Randomized clinical trials of patients with acute myocardial infarction-related cardiogenic shock: a systematic review of used cardiogenic shock definitions and outcomes. Kardiol Pol. 2021; 79(9): 1003-1015, doi: 10.33963/KP.a2021.0072.

\section{REFERENCES}

1. Virani SS, Alonso A, Benjamin EJ, et al. American Heart Association Council on Epidemiology and Prevention Statistics Committee and Stroke Statistics Subcommittee. Heart disease and stroke statistics-2020 update: a report from the American Heart Association. Circulation. 2020; 141(9): e139-e596, doi: 10.1161/CIR.0000000000000757, indexed in Pubmed: 31992061.

2. Goldberg RJ, Makam RC, Yarzebski J, et al. Decade-Long trends (20012011 ) in the incidence and hospital death rates associated with the in-hospital development of cardiogenic shock after acute myocardial infarction. Circ Cardiovasc Qual Outcomes. 2016; 9(2): 117-125, doi: 10.1161/CIRCOUTCOMES.115.002359, indexed in Pubmed: 26884615.

3. Helgestad $\mathrm{OKL}$, Josiassen J, Hassager $\mathrm{C}$, et al. Temporal trends in incidence and patient characteristics in cardiogenic shock following acute myocardial infarction from 2010 to 2017: a Danish cohort study. Eur J Heart Fail. 2019; 21(11): 1370-1378, doi: 10.1002/ejhf.1566, indexed in Pubmed: 31339222. 
4. Lindholm M, Køber L, Boesgaard S. Cardiogenic shock complicating acute myocardial infarction Prognostic impact of early and late shock development. Eur Heart J. 2003; 24(3): 258-265, doi: 10.1016/s0195668x(02)00429-3.

5. Schrage B, Ibrahim K, Loehn T, et al. Impella support for acute myocardial infarction complicated by cardiogenic shock. Circulation. 2019; 139(10): 1249-1258, doi: 10.1161/CIRCULATIONAHA.118.036614, indexed in Pubmed: 30586755.

6. Poulidakis $E$, Spaulding C. Cardiac assist devices in cardiogenic shock. Circulation. 2019; 139(10): 1259-1261, doi: 10.1161/CIRCULATIONAHA.118.038855, indexed in Pubmed: 30865480.

7. van Diepen S, Katz JN, Albert NM, et al. American Heart Association Council on Clinical Cardiology; Council on Cardiovascular and Stroke Nursing; Council on Quality of Care and Outcomes Research; and Mission: Lifeline. Contemporary management of cardiogenic shock: a scientific statement from the American Heart Association. Circulation. 2017; 136(16): e232-e268, doi: 10.1161/CIR.0000000000000525, indexed in Pubmed: 28923988.

8. Zeymer U, Bueno H, Granger CB, et al. Acute Cardiovascular Care Association position statement for the diagnosis and treatment of patients with acute myocardial infarction complicated by cardiogenic shock: A document of the Acute Cardiovascular Care Association of the European Society of Cardiology. Eur Heart J Acute Cardiovasc Care. 2020; 9(2): 183-197, doi: 10.1177/2048872619894254, indexed in Pubmed: 32114774.

9. Burstein B, Tabi M, Barsness GW, et al. Association between mean arterial pressure during the first 24 hours and hospital mortality in patients with cardiogenic shock. Crit Care. 2020; 24(1): 513, doi: 10.1186/s13054-02003217-6, indexed in Pubmed: 32819421.

10. Hochman JS, Sleeper LA, Webb JG, et al. Early revascularization in acute myocardial infarction complicated by cardiogenic shock. SHOCK investigators. Should we emergently revascularize occluded coronaries for cardiogenic shock. N Engl J Med. 1999; 341(9): 625-634, doi: 10.1056/NEJM199908263410901, indexed in Pubmed: 10460813.

11. Thiele H, Zeymer U, Neumann FJ, et al. IABP-SHOCK II Trial Investigators. Intraaortic balloon support for myocardial infarction with cardiogenic shock. N Engl J Med. 2012; 367(14): 1287-1296, doi: 10.1056/NEJMoa1208410, indexed in Pubmed: 22920912.

12. Jentzer JC, van Diepen S, Henry TD. Understanding how cardiac arrest complicates the analysis of clinical trials of cardiogenic shock. Circ Cardiovasc Qual Outcomes. 2020; 13(9): e006692, doi: 10.1161/CIRCOUTCOMES.120.006692, indexed in Pubmed: 32862695.

13. Thiele H, Akin I, Sandri M, et al. CULPRIT-SHOCK Investigators. PCI strategies in patients with acute myocardial infarction and cardiogenic shock. N Engl J Med. 2017; 377(25): 2419-2432, doi: 10.1056/NEJMoa1710261, indexed in Pubmed: 29083953.

14. Josiassen J, Lerche Helgestad OK, Møller JE et al. Hemodynamic and metabolic recovery in acute myocardial infarction-related cardiogenic shock is more rapid among patients presenting with out-of-hospital cardiac arrest. PLoS One. 2020; 23; 15(12): e0244294, doi: 10.1371/journal. pone.0244294, indexed in Pubmed: 33362228.

15. Alexander JH, Reynolds HR, Stebbins AL, et al. TRIUMPH Investigators. Effect of tilarginine acetate in patients with acute myocardial infarction and cardiogenic shock: the TRIUMPH randomized controlled trial. JAMA. 2007; 297(15): 1657-1666, doi: 10.1001/jama.297.15.joc70035, indexed in Pubmed: 17387132.

16. Bochaton T, Huot L, Elbaz M, et al. IMPELLA-STIC investigators. Mechanical circulatory support with the Impella ${ }^{\circledR}$ LP5.0 pump and an intra-aortic balloon pump for cardiogenic shock in acute myocardial infarction: The IMPELLA-STIC randomized study. Arch CardiovasC Dis. 2020; 113(4): 237-243, doi: 10.1016/j.acvd.2019.10.005, indexed in Pubmed: 31740272.

17. Tousek $P$, Rokyta $R$, Tesarova J, et al. Routine upfront abciximab versus standard periprocedural therapy in patients undergoing primary percutaneous coronary intervention for cardiogenic shock: The PRAGUE-7 Study. An open randomized multicentre study. Acute Card Care. 2011; 13(3): 116-122, doi: 10.3109/17482941.2011.567282, indexed in Pubmed: 21526919.

18. Ouweneel DM, Eriksen E, Sjauw KD, et al. Percutaneous mechanical circulatory support versus intra-aortic balloon pump in cardiogenic shock after acute myocardial infarction. J Am Coll Cardiol. 2017; 69(3): 278-287, doi: 10.1016/j.jacc.2016.10.022, indexed in Pubmed: 27810347.

19. Prondzinsky $\mathrm{R}$, Lemm H, Swyter $M$, et al. Intra-aortic balloon counterpulsation in patients with acute myocardial infarction complicated by cardiogenic shock: the prospective, randomized IABP SHOCK Trial for attenuation of multiorgan dysfunction syndrome. Crit Care Med. 2010; 38(1): 152-160, doi: 10.1097/CCM.0b013e3181b78671, indexed in Pubmed: 19770739.

20. Seyfarth $M$, Sibbing D, Bauer l, et al. A randomized clinical trial to evaluate the safety and efficacy of a percutaneous left ventricular assist device versus intra-aortic balloon pumping for treatment of cardiogenic shock caused by myocardial infarction. J Am Coll Cardiol. 2008; 52(19): 15841588, doi: 10.1016/j.jacc.2008.05.065, indexed in Pubmed: 19007597.

21. Li Jl, Xue H, Wang Bs, et al. Effect of prolonged intra-aortic balloon pumping in patients with cardiogenic shock following acute myocardial infarction. Med Sci Monit. 2007; 13(6): CR270-CR274, indexed in Pubmed: 17534233.

22. Thiele $\mathrm{H}$, Sick $\mathrm{P}$, Boudriot $\mathrm{E}$, et al. Randomized comparison of intra-aortic balloon support with a percutaneous left ventricular assist device in patients with revascularized acute myocardial infarction complicated by cardiogenic shock. Eur Heart J. 2005; 26(13): 1276-1283, doi: 10.1093/eurheartj/ehi161, indexed in Pubmed: 15734771.

23. Pan Y, Lu Z, Hang J, et al. Effects of low-dose recombinant human brain natriuretic peptide on anterior myocardial infarction complicated by cardiogenic shock. Braz J Cardiovasc Surg. 2017; 32(2): 96-103, doi: 10.21470/1678-9741-2016-0007, indexed in Pubmed: 28492790.

24. Jin YY, Gao H, Zhang XY, et al. Shenfu Injection inhibits inflammation in patients with acute myocardial infarction complicated by cardiac shock. Chin J Integr Med. 2017; 23(3): 170-175, doi: 10.1007/s11655-016-2749-x, indexed in Pubmed: 28028723.

25. Barillà F, Pannarale G, Torromeo C, et al. Ivabradine in patients with st-elevation myocardial infarction complicated by cardiogenic shock: a preliminary randomized prospective study. Clin Drug Investig. 2016; 36(10): 849-856, doi: 10.1007/s40261-016-0424-9, indexed in Pubmed: 27312076.

26. Fuhrmann JT, Schmeisser A, Schulze MR, et al. Levosimendan is superior to enoximone in refractory cardiogenic shock complicating acute myocardial infarction. Crit Care Med. 2008; 36(8): 2257-2266, doi: 10.1097/CCM.0b013e3181809846, indexed in Pubmed: 18664782.

27. Dzavík V, Cotter G, Reynolds HR, et al. SHould we inhibit nitric Oxide synthase in Cardiogenic shocK 2 (SHOCK-2) investigators. Effect of nitric oxide synthase inhibition on haemodynamics and outcome of patients with persistent cardiogenic shock complicating acute myocardial infarction: a phase II dose-ranging study. Eur Heart J. 2007; 28(9): 1109-1116, doi: 10.1093/eurheartj/ehm075, indexed in Pubmed: 17459901.

28. García-González MJ, Domínguez-Rodríguez A, Ferrer-Hita JJ, et al. Cardiogenic shock after primary percutaneous coronary intervention: effects of levosimendan compared with dobutamine on haemodynamics. Eur J Heart Fail. 2006; 8(7): 723-728, doi: 10.1016/j.ejheart.2006.01.007, indexed in Pubmed: 16492404.

29. Urban P, Stauffer JC, Bleed D, et al. A randomized evaluation of early revascularization to treat shock complicating acute myocardial infarction. The (Swiss) Multicenter Trial of Angioplasty for Shock-(S)MASH. Eur Heart J. 1999; 20(14): 1030-1038, doi: 10.1053/euhj.1998.1353, indexed in Pubmed: 10383377.

30. Fuernau G, Beck J, Desch S, et al. Mild hypothermia in cardiogenic shock complicating myocardial infarction. Circulation. 2019; 139(4): 448-457, doi: 10.1161/CIRCULATIONAHA.117.032722, indexed in Pubmed: 30026282.

31. Lobo AS, Sandoval Y, Henriques JP, et al. Cardiogenic shock management: international survey of contemporary practices. J Invasive Cardiol. 2020; 32(10): 371-374, indexed in Pubmed: 32999090.

32. Menon V, Slater J, White $\mathrm{H}$, et al. Acute myocardial infarction complicated by systemic hypoperfusion without hypotension: report of the SHOCK trial registry. Am J Med. 2000; 108(5): 374-380, doi: 10.1016/s00029343(00)00310-7.

33. Danzi G, Cuspidi C. Diastolic blood pressure and myocardial damage. J Am Coll Cardiol. 2017;69(12): 1645-1646, doi: 10.1016/j.jacc.2016.11.086.

34. Vincent JL, Quintairos E Silva A, Couto L, et al. The value of blood lactate kinetics in critically ill patients: a systematic review. Crit Care. 2016; 20(1): 257, doi: 10.1186/s13054-016-1403-5, indexed in Pubmed: 27520452. 
35. Frydland M, Møller JE, Wiberg S, et al. Lactate is a prognostic factor in patients admitted with suspected ST-elevation myocardial infarction. Shock. 2019; 51(3): 321-327, doi: 10.1097/SHK.0000000000001191, indexed in Pubmed: 30286032.

36. Udesen NJ, Møller JE, Lindholm MG, et al. DanGer Shock investigators. Rationale and design of DanGer shock: Danish-German cardiogenic shock trial. Am Heart J. 2019;214:60-68, doi: 10.1016/j.ahj.2019.04.019, indexed in Pubmed: 31176289.

37. Verbrugge $\mathrm{FH}$, Guazzi $\mathrm{M}$, Testani JM, et al. Altered hemodynamics and end-organ damage in heart failure: impact on the lung and kidney. Circulation. 2020; 142(10): 998-1012, doi: 10.1161/CIRCULATIONAHA.119.045409, indexed in Pubmed: 32897746.

38. Grand J, Kjaergaard J, Bro-Jeppesen J, et al. Cardiac output, heart rate and stroke volume during targeted temperature management after out-of-hospital cardiac arrest: association with mortality and cause of death. Resuscitation. 2019; 142: 136-143, doi: 10.1016/j.resuscitation.2019.07.024, indexed in Pubmed: 31362081.

39. Grand J, Bro-Jeppesen J, Hassager C, et al. Cardiac output during targeted temperature management and renal function after out-of-hospital cardiac arrest.J Crit Care. 2019; 54:65-73, doi: 10.1016/j.jcrc.2019.07.013, indexed in Pubmed: 31362189.

40. Wetterslev M, Møller-Sørensen H, Johansen RR, et al. Systematic review of cardiac output measurements by echocardiography vs. thermodilution: the techniques are not interchangeable. Intensive Care Med. 2016;42(8): 1223-1233, doi: 10.1007/s00134-016-4258-y, indexed in Pubmed: 26932349.

41. Josiassen J, Helgestad OKL, Møller JE et al. Cardiogenic shock due to predominantly right ventricular failure complicating acute myocardial infarction. Eur Heart J Acute Cardiovasc Care. 2021; 10(1): 33-39, doi: 10.1093/ehjacc/zuaa010, indexed in Pubmed: 33620420.

42. Ma TS, Paniagua D, Denktas AE, et al. Usefulness of the sum of pulmonary capillary wedge pressure and right atrial pressure as a congestion index that prognosticates heart failure survival (from the evaluation study of congestive heart failure and pulmonary artery catheterization effectiveness trial). Am J Cardiol. 2016; 118(6): 854-859, doi: 10.1016/j. amjcard.2016.06.040, indexed in Pubmed: 27474338.
43. Yancy CW, Jessup M, Bozkurt B, et al. WRITING COMMITTEE MEMBERS, American College of Cardiology Foundation/American Heart Association Task Force on Practice Guidelines. 2013 ACCF/AHA guideline for the management of heart failure: a report of the American College of Cardiology Foundation/American Heart Association Task Force on practice guidelines. Circulation. 2013; 128(16): e240-e327, doi: 10.1161/CIR. 0b013e31829e8776, indexed in Pubmed: 23741058.

44. Obokata M, Kane GC, Reddy YNV, et al. Role of diastolic stress testing in the evaluation for heart failure with preserved ejection fraction: a simultaneous invasive-echocardiographic study. Circulation. 2017; 135(9): 825-838, doi: 10.1161/CIRCULATIONAHA.116.024822, indexed in Pubmed: 28039229.

45. Bro-Jeppesen J, Hassager C, Wanscher M, et al. Targeted temperature management at $33^{\circ} \mathrm{C}$ versus $36^{\circ} \mathrm{C}$ and impact on systemic vascular resistance and myocardial function after out-of-hospital cardiac arrest: a sub-study of the target temperature management trial. Circ Cardiovasc Interv. 2014; 7(5):663-672, doi: 10.1161/CIRCINTERVENTIONS.114.001556, indexed in Pubmed: 25270900.

46. Bro-Jeppesen J, Johansson PI, Hassager C, et al. Endothelial activation/ /injury and associations with severity of post-cardiac arrest syndrome and mortality after out-of-hospital cardiac arrest. Resuscitation. 2016; 107: 71-79, doi: 10.1016/j.resuscitation.2016.08.006, indexed in Pubmed: 27523954.

47. Jentzer JC, van Diepen S, Barsness GW, et al. Cardiogenic shock classification to Predict mortality in the cardiac intensive care unit. J Am Coll Cardiol.2019; 74(17):2117-2128, doi: 10.1016/j.jacc.2019.07.077, indexed in Pubmed: 31548097.

48. Richard C, Warszawski J, Anguel N, et al. French Pulmonary Artery Catheter Study Group. Early use of the pulmonary artery catheter and outcomes in patients with shock and acute respiratory distress syndrome: a randomized controlled trial. JAMA. 2003; 290(20): 2713-2720, doi: 10.1001/jama.290.20.2713, indexed in Pubmed: 14645314.

49. Singer M, Deutschman C, Seymour C, et al. The third international consensus definitions for sepsis and septic shock (Sepsis-3). JAMA. 2016; 315(8): 801-810, doi: 10.1001/jama.2016.0287. 